\title{
FUTÓ Péter
}

\section{A VÁLLALKOZÁSOKAT ÉRINTŐ JOGI SZABÁLYOZÁS HATÁSVIZSGÁLATA}

\author{
II. RÉSZ
}

A szabályozás az állam és a vállalkozások kapcsolatának egyik lényeges aspektusa. A dolgozat a szabályozás minốségét javító kormányzati eszközöket és stratégiákat elemzi. A májusi számunkban megjelent elsố rész áttekintette, hogy a fejlett országokban és a nemzetközi szervezetekben, így az Európai Unióban, ezen belül az EU-hoz újonnan csatlakozott országokban milyen hatásvizsgálati rendszerek fejlődtek ki, és ezek hogyan intézményesültek. A szerzố a második részben ismerteti a Világbank és az OECD azon kutatásait, melyek igazolták, hogy a vállalkozások szabályozási környezete, a cégeket terheló adminisztratív teher mértéke igen erôteljesen befolyásolja az országok versenyképességét. Végül az írás bemutatja, hogy e fejlôdés során az elmúlt két évtizedben milyen általános módszertani elvek és eszközök kristályosodtak ki a hatáselemzésben. ${ }^{1}$

\section{Kulcsszavak: vállalkozások, állami szabályozások, hatásvizsgálat}

A párizsi székhelyú Gazdasági Együttmúködési és Fejlesztési Szervezet (OECD) 1961 szeptemberében kezdte meg múködését. A csoportosulásnak jelenleg 30 tagországa van, köztük a legfejlettebb országok. Magyarország 1996 óta tagja a közösségnek. Az OECD azt tekinti fố céljának, hogy elősegítse tagországaiban a demokratikus kormányzást és a gyors ütemú gazdasági növekedést. Tevékenysége elsôsorban a jó kormányzás (good governance) módszereinek, a közintézmények stratégiafejlesztési eszközeinek kutatására terjed ki, ennek rendeli alá kiterjedt statisztikai munkáját és szakpolitikai irányultságú felméréseit. A szervezet kötelezô erejú döntéseket nem hoz, csupán javaslatok útján befolyásolja a tagországaiban folyó kormányzati munkát.

Mivel a szabályozás a kormányzatok és a vállalkozások közötti kapcsolattartás egyik legfontosabb eszköze, az OECD már a kilencvenes években készített javaslatokat a szabályalkotás minőségének vizsgálatára, tervezésére. ${ }^{2}$ Az OECD felismerte, hogy a szabályozás minôségének javítása fokozza a gazdasági teljesítményt, amit a szervezet egyik kutatási projektje tudományos módszerrel is igazolt. ${ }^{3}$ Az OECD a 90-es évek közepe óta határozatok és javaslatok sorát fogal- mazta meg a jó kormányzás és a szabályozási reform elveiről. ${ }^{4}$ A szervezet 1998 és 2004 között húsz ország szabályozási reformtevékenységét világította át. ${ }^{5}$

$\mathrm{Az}$ ezredfordulón 14 OECD-tagállam jelentette, hogy intézményes szabályozási hatásvizsgálati tevékenység segíti ebben a törekvésében, a fejlődő országokból azonban csak elszigetelt hasonló kezdeményezésekról érkezett hír. ${ }^{6}$ A Cseh Köztársaságban, Koreában és Mexikóban törvényt, az USA-ban elnöki rendeletet hoztak alkalmazásáról, valamint kormányrendeletek írják elő használatát Ausztráliában, Ausztriában, Dániában, az Egyesült Királyságban, Finnországban, Franciaországban, Hollandiában, Japánban, Kanadában, Lengyelországban, Magyarországon, Németországban, Norvégiában, Olaszországban, Portugáliában, Új-Zélandon és Svédországban. A szabályozási hatásvizsgálati eljárások minőségi vizsgálatát az Egyesült Királyságban és Mexikóban rendszeresen elvégzik, az erre szakosodott kormányszervek segítségével.

A szervezet évente áttekinti a kisvállalkozások helyzetét a tagállamokban, és jelentéseiben nagy szerepet szán az adminisztratív egyszerúsítéseknek, mint a vállalkozástámogatási politika legfontosabb eszközének. ${ }^{7}$ Az adminisztratív terhek csökkentése jelenleg a kisvál- 
lalkozás-fejlesztési politika egyik legfontosabb célja az OECD-tagállamokban. Ezt a célt szolgálják a tagországok alábbi intézkedései:

- szabályozási nyelvezet egyszerúsítésére törekvô kezdeményezések,

- szabálykövetést megkönnyítő technikai segítségnyújtás,

- korlátozó jogszabályok, melyek kivételt tesznek a kisebb cégekkel,

- egyablakos ügyintézói rendszerek,

- kisvállalkozásoknak szánt speciális információs anyagok.

\section{Kormányzati stratégiák a bürokrácia csökkentésére}

Az OECD-országokban a vállalkozások és az állampolgárok egyik leggyakoribb panasza a kormányzat által támasztott túl sok és túl bonyolult papírmunka, adminisztráció. A tagországok kormányai az elmúlt két évtizedben nekiláttak a bürokrácia (red tape) felülvizsgálatához és egyszerúsítéséhez. 2003-ban az OECD egyik felmérése alapján tanulmány készült a vállalkozókat érintô adminisztrációs eljárások egyszerúsítésének követendő példáiról. ${ }^{8}$ A felmérésben Ausztrália, Franciaország, Hollandia, Mexikó, Korea, az Egyesült Királyság, az USA és más országok szerepelnek országonként néhány esettanulmánnyal.

Az OECD-tagországok kormányszervei korábban elsôsorban az egyes szabályozó intézmények szintjén kísérleteztek egyszerúsítési törekvésekkel (bottom-up kezdeményezések). Ezek mellett egyre több országban tûnnek fel a központi kormányzatok ügyfélbarát intézkedései is (top-down kezdeményezések). Az adminisztrációt egyszerúsítố projektek leggyakrabban az alábbi megoldási lehetôségek, modellek közül szoktak választani.

Prevenció. Megfigyelhetô, hogy egyes országokban elmozdulnak attól a megközelítéstől, amely a bürokráciát utólag kísérli meg csökkenteni, ehelyett teret nyer az a megközelítés, amely a szükségtelen és ésszerütlen terheket már azok bevezetése elốtt kívánja megakadályozni.

Információtechnológiai eszközök. Az IT fejlődése és terjedése, az úgynevezett e-kormányzati megoldások lehetősége egyre növekvő nyomás alá helyezi a kormányzatokat. Az IT kézzel fogható lehetôséget ad a papírmunka csökkentésére, másrészt az internet révén az érintetteknek lehetôsége van a hatóságokkal való kapcsolattartásra és a gyors és intenzív reakcióra.

Egyablakos ügyintézói rendszerek. Az egyablakos rendszerek - köztük elsôsorban az online ügyintézést lehetôvé tevő megoldások - szinte minden OECD-tag- országban teret hódítanak. Így például az USA-ban a munkaügyi szabályozás végrehajtását, Nagy-Britanniában pedig a kisvállalkozásokat érintố szabályozások eljárásait sikerült egy-egy internetes portálba integrálni. Több országban - így Magyarországon is - kormányzati weboldalakat állítottak fel, és ezekben igyekeznek egyesíteni a különböző szabályozási területek, tárcák egyablakos ügyintéző rendszereit (merger of one-stop shops). ${ }^{9}$ A folyamat intézményi bonyolultsága miatt nincs olyan tagország, amely a közigazgatási ügyintézés teljes spektrumát egyetlen egyablakos rendszerben egységesítette volna, de számos megoldás ismeretes, melyek az egyes tárcákon belül teszik hozzáférhetôvé a hivatalok múködését. Az egyablakos ügyintézői rendszerek jelentős idő- és erőforrás-megtakarítást hozhatnak, és igen népszerúek, ezért a vállalati szektor ügyfélkapcsolati munkájának tervezói is e megoldás felé orientálódnak.

Vállalkozások engedélyeztetési folyamatainak egyszerüsitése (simplification of business licensing). A bonyolult engedélyeztetési eljárások komoly károkat okoznak, mert valós és vélt akadályt állítanak az újonnan induló vállalkozások elé. A már piacon lévő cégek pedig erôs késztetést érezhetnek arra, hogy a kormányzatot úgy befolyásolják, hogy az engedélyeztetési szabályokkal az ô versenypozícióikat védje. Az engedélyeztetés egyszerúsítése kitüntetetten fontos az adminisztratív terhek csökkentésében, mert rövid idő alatt látványos eredmény érhetô el vele.

Hatóságoknak elóírt idókorlátok (time limits). Az adminisztratív terhek lényeges eleme a várakozási idô, ami egy kérelem benyújtása és az arról való döntés kiértesítése között telik el. Egyre több országban terjed el, hogy határidốt szabnak az egyes kormányszerveknek az ügyek intézésére. Az idókorlátot szabó intézkedés akkor igazán ügyfélbarát, ha elôírja: amennyiben a hivatal elmulasztja a választ idốben megadni az ügyfélnek, akkor automatikusan teljesül az ügyfél kérése (,silence is consent” szabály). Az időkorlát megszabása lényeges költségcsökkenést hozhat a vállalkozások és az állampolgárok számára és növeli a kormányzati szervek elszámoltathatóságát és készségességét.

Kis- és középvállalkozások elónyben részesitése. Több OECD-országban oly módon is igyekeznek fokozni a kisebb vállalkozások versenyképességét, hogy azok egyes szabályozások végrehajtása során felmentést élveznek a szabályozás bizonyos pontjai alól.

Új szervezeti modellek bevezetése a bürokrácia csökkentésére. Több OECD-országban a közigazgatás szervezeti formáinak reformjába illesztik az adminisztratív terhek csökkentését. Egyes szabályozási területeken az vált be, hogy tárcaszinten hoznak létre olyan specializált egységeket, amelyek feladata az adminiszt- 
ráció egyszerúsítése egy meghatározott eszköz (pl. információtechnológia) segítségével, vagy egy meghatározott célcsoport (pl. kisvállalkozások) érdekében. Más esetekben felsóbb kormányzati szinten létesítenek az adminisztráció egyszerúsítésére szakosodott egységeket. Olcsó és szakszerú megoldás lehet az adminisztrációcsökkentés feladatának delegálása a kormány által létrehozott külső bizottságokba, melyek tagjainak többsége nem-kormányzati, akadémiai és vállalkozói szervezetek képviselője.

Dereguláció. E projektek végrehajtása során tömegesen vizsgálnak felül létezó jogszabályokat, és helyezik hatályon kívül az elavultakat, feleslegeseket, ellentmondásokkal terhelteket. A dereguláció jellegzetes eredménye lehet a létezố jogszabályok összevonása. Ezen a területen sok fejlett ország nem tart lépést saját deklarált terveivel, így Magyarország sem.

A tanulságok szerint a bürokrácia csökkentése látványos eredményekhez vezethet már rövid időtávon belïl. Ez a megközelítés megfelel a politikai ciklus rövidségének, így alkalmas a választópolgárok reformok iránti elkötelezettségének előmozdítására. Ugyanakkor fennáll az a veszély, hogy a szélesebb spektrumú szabályozási reformoktól eltereli a figyelmet. Ezért az adminisztráció csökkentését egy átfogó, a szabályozás minőségét folyamatosan napirenden tartó politika részeként kell kezelni.

\section{A gazdasági szabályozás versenyképességi hatásainak mérése}

Az OECD egyik hatásvizsgálati modelljének bemenete egy olyan adatbázis, amely országonként tartalmazza a vállalkozások szabályozásának számos jellegzetességét. A regressziós számítás célja, hogy kimutassa: mekkora hatása van a gazdasági szabályozás szigorának az egy fớre jutó GDP-re. ${ }^{10}$ A kutatás során az egyes országokban érvényesülő gazdasági szabályozók jellemzőit részletes kérdőív segítségével térképezték fel. Az 1998-tól 2002-ig tartó felméréssorozat országonként évente 1500 különböző szabályozást vizsgált abból a szempontból, hogy ezek mennyiben korlátozzák a gazdasági tevékenységet, hogyan befolyásolják a versenyképességet. A makrogazdasági és szektorspecifikus szabályozók köre törvényekre, jogszabályokra és adminisztratív eljárásokra terjedt ki.

A kérdőívre eredetileg 27 ország válaszolt, de ebból a mintából utóbb 3 ország kiesett, köztük sajnos Magyarország is.

Az adatbázis segítségével a kutatók kidolgoztak egy olyan metrikát, az úgynevezett „OECD Economic Regulation Index-et" amelynek segítségével az orszá- gokat képesek voltak sorba rendezni aszerint, hogy a szabályozások szigora mennyire fékezi a gazdasági tevékenységet. A kompozit index mögött álló primér mutatók a legtöbb belföldi jellegú gazdasági szabályozásra kiterjednek. ${ }^{11}$ Így például a közúti szállítási ágazat jogszabályi környezetének értékelése során számszerúsítik a gépkocsivezetôk pihenóidejének megszabására vonatkozó szabályozás hatását is.

Az egyes országok szintjén a kompozit index egyegy értéke fejezte ki az adott országban érvényesülő szabályozások vállalkozásbarátságosságának mértékét. Ebben a metrikában a szabályozások teljes hiánya 0 értéket kapott, az Amerikai Egyesült Államokban a szabályozás versenyképességi hatásaihoz rendelt érték 1-es szintú volt, Ausztráliában és Svédországban 1,3 és így növekszik az érték egészen Törökországig, ahol 3,1, majd Olaszországig, amelyben a 24 ország közül a vállalkozások szabályozási környezete a legkedvezótlenebb, 3,5-ös értéket vette fel. Ezt a változót azután az egyik magyarázó változó szerepében belehelyezték egy olyan regressziós egyenletbe, ahol a magyarázni kívánt mennyiség az egy före jutó nemzeti jövedelem volt, a többi magyarázó változó pedig az adott ország egyéb demográfiai, képzettségi és külgazdasági sajátosságait fejezte ki.

A fenti módszert követő regressziós számítások egyik legfontosabb eredménye, hogy a szóban forgó 24 ország esetében az „OECD Economic Regulation Index" egységnyi megváltozása 1300 dollárral csökkentette az egy före jutó GDP-t. Ezt az értéket szabályozási költségként kell értelmezni. Más szóval: amikor egy adott szabályozási szigorral jellemezhetô országról áttérünk egy másik országra, amely

- minden figyelembe vett demográfiai, képzettségi és külgazdasági szempontból azonos tulajdonságú, de

- egy egységnyi „OECD Economic Regulation Index" mértékben szigorúbb,

akkor átlagosan egy 1300 dollárral kisebb „egy före jutó GDP- jứ" országhoz jutunk.

\section{Az üzleti környezet vizsgálata a Világbanknál: a „Doing business” projekt célja és módszere}

$\mathrm{Az}$ egyes országok nemzetközi versenyképességéról ${ }^{12}$ és az azokban érvényesülő gazdasági szabadságról ${ }^{13}$ kutatómúhelyek egész sora állít össze és tesz közzé indikátorokat, melyek az ott múködő vállalkozások számára érvényes általános gazdasági és politikai feltételeket jellemzik. Elsődleges céljuk többnyire az, hogy a nemzetközi befektetôket és a helyben múködő vállalkozásokat informálják, orientálják. Jelzőszámaik 
és az így kialakított - általában 150-180 országra kiterjedő - országsorrendek egymástól eltérô módszereken alapulnak, a legkülönbözốbb jellegú adatgyújjtéseken alapulnak.

A Világbank 2004 óta közöl éves jelentéseket arról, hogy a világ országaiban a vállalkozásokat milyen szabályozások érintik, hogy e törvényeknek és rendeleteknek milyen hatásaik vannak a gazdálkodásra. A jelentéssorozat címe „Doing Business”. ${ }^{14}$ A kutatássorozatot az a konszenzus hívta életre, mely szerint egy ország gazdasági teljesítményét nemcsak a makrogazdasági politika határozza meg, hanem nagy szerepe van a vállalkozásokat érintő szabályozás minőségének, és annak, hogy milyen munkát végeznek a szabálykövetést felügyelô intézmények.

A „Doing Business” kutatás a kis- és középvállalkozásokra fókuszál, elemzése országonként a helyi feladatokkal foglalkozó szakértók által a szabályozás különbözó területeiról nyújtott, ellenőrzött és összehasonlítható információkon alapul. Értékeli a vállalkozásokat leginkább érintő jogszabályokat és az azokat betartató intézményeket, továbbá informál arról, hogy a vállalkozások milyen mértékben vannak kiszolgáltatva azoknak az üzleti szolgáltatóknak, akiknek munkáját kötelezôen igénybe kell venniük (ügyvédek, könyvelő́k, könyvvizsgálók).

A keletkező adatbázis összehasonlító keretet ad a kormányzatok szabályozási reformjainak egybevetéséhez, információkat szolgáltat a reformtervekhez, áttekinthetôvé teszi a különböző indikátorok mentén jól teljesító országok gyakorlatát. Mivel a nemzetközi támogatások és segélyek jó intézményi körülmények között hasznosulnak a legjobban, ezért ellenőrizhetôvé teszi a segélyek hatékonyságát és segíti a teljesítményalapú finanszírozást. Empirikusan tesztelhetôvé teszi a szabályozás és a gazdasági fejlődés kapcsolatáról szóló elméleteket.

A sorozat egyes évkönyvei egy átlagos vállalkozás életének alapvetô aspektusait, üzleti folyamatait tekintik át.

Így például a 2004-es évkönyvben ilyen kiemelt aspektus - vagy más szóval: szabályozott üzleti folyamat - volt

(a) vállalkozás elindítása,

(b) a munkaerō felvétele és elbocsátása,

(c) a szerződések előírásainak kikényszerítése,

(d) a hitelhez jutás, valamint

(e) a vállalkozás megszüntetése.

Az elemzés 2005-ben az alábbi üzleti folyamatokkal bővült:

(f) a tulajdon bejegyeztetése és

(g) a befektetések védelme. 2006-ban a vizsgált területekhez hozzávették az alábbiakat:

(h) kormányzati engedélyek beszerzése,

(i) az adófizetés és

(j) a külkereskedelem.

A kiadványsorozat kapcsán a kutatók kétféle indikátort fejlesztettek ki.

- A szabályozás tartalmára jellemző indikátorok: ilyen mutatószám például a vállalkozás bejegyzéséhez szükséges eljárások száma, vagy a munkaerő-felvétel és munkaerô-elbocsátás merevségét jelzô index.

- A szabályozás eredményének indikátorai: ezek a mutatók a szabályozás idő- és költségvonzatát mérik, például mennyi ideig tart és mennyibe kerül bejegyeztetni egy vállalkozást, kikényszeríteni egy szerződés rendelkezéseit vagy csődeljáráson keresztülmenni.

A felmérés és elemzés módszere minden egyes megvizsgált üzleti folyamat esetén azonos:

- A központi kutatócsapat helyi tanácsadók segítségével összegyújti az adott országban az adott üzleti folyamatot érintô, érvényben lévô szabályozásokat.

- A szabályozás elemzése alapján egy kérdőívet készítenek az adott üzleti folyamat területén jártas helyi szakértóknek, általában vállalati ügyekkel foglalkozó jogászoknak, ügyvédeknek, tanácsadóknak és bíróknak. E kérdőív segítségével értékelhetố az adott üzleti folyamat szabályozása.

- A helyi szakértók és a központi kutatócsapat között több, általában négyfordulós interakcióra kerül sor. Ezek során az előzetes eredményeket tudományos és gyakorlati szakembereknek mutatják be, majd a kérdőív finomítására, újabb értékelési szempontok beemelésére és újabb adatgyưjitési fordulókra kerül sor. Így például a vállalkozás indítása kapcsán cégügyekkel foglalkozó ügyvédek javaslatára a korábbi indikátorok mellé a minimális tókekövetelményt is számításba vették, mivel a kezdô cégek számára ez sokszor jelent effektív belépési korlátot.

- A felmérés eredménye indikátorok egy halmaza, melyek viszonylag egyszerúen és összehasonlítható módon előállíthatók a különböző országokban.

A jelzőszámok összehasonlíthatóságát úgy biztosítják, hogy indikátoronként megegyeznek egy nagyon egyértelmú, valamennyi országban gyakran előforduló helyzetben, amelyet a vállalkozás típusával és az elintézni kívánt ügy paramétereivel pontosan definiálnak. A kérdőív tehát egy viszonylag jellemző hipotetikus esetre épül. 
Például 2006-ban a „vállalkozás beindításának nehézsége" nevú indikátor és annak összetevới az alábbi feltételezéseken nyugszanak. A bejegyzendő cég:

- korlátolt felelősségú társaság,

- az ország legnépesebb városában múködik,

- 100\%-ban hazai, 5 magánszemély tulajdona,

- induló tôkéje az egy fôre jutó GDP tízszerese, és azt 2005 végén készpénzben befizették,

- általános ipari vagy kereskedelmi tevékenységet kíván folytatni, nem kíván külkereskedelmi ügyleteket végezni, nem termel speciálisan adóztatott termékeket (alkohol, dohány), nem szennyezi jelentósen a környezetet,

- helyiségeit bérli, nincs ingatlana,

- nem jogosult sem beruházási, sem más kedvezményre,

- múködését követően 50 alkalmazottja van, mindegyikük helybeli,

- éves forgalma legalább az egy fớre jutó GDP százszorosa,

- társasági szerződése nem haladja meg a tíz oldalt.

Ez a megközelítés széles körben értelmezhetóvé teszi a kapott eredményeket, és keretek közé utasítja az „attól függ”, a „nálunk ez bonyolultabb” és a „nálunk ez nem releváns" jellegú ellenvetéseket.

A ,vállalkozás elindításának nehézségi foka” nevú indikátornak négy összetevője van. (1) a vállalkozás bejegyzéséhez szükséges kötelező (hatósági, közjegyzối, ügyvédi, könyvelôi stb.) eljárások száma, (2) a vállalkozás bejegyzéséhez szükséges idó, (3) költség, (4) minimális kezdôtóke.

A vállalkozás elindításához szükséges eljárások kapcsán a módszer a következő feltevésekkel él:

- Eljárásnak számít minden interakció a vállalkozás alapítói és a külső felek (kormányhivatalok, ügyvédek, könyvvizsgálók, közjegyzók) között. A vállalkozás alapítói, vezetői és alkalmazottaik közötti interakciók nem számítanak bele ebbe az indikátorba.

- Az alapítók minden folyamatot maguk végeznek el, könyveloók és ügyvédek segítsége nélkül, hacsak nem kötelező ilyen harmadik fél igénybevétele.

- A szabályozás által nem kötelezően előírt folyamatok nem veendốk számításba.

- Alternatív eljárási utak esetén a legkisebb időigényú legális eljárási út számít az indikátorba, feltéve, hogy ez széles körben igénybe vehetô.

- Csak az olyan folyamatok veendók számításba, amelyek minden vállalkozás számára kötelezóek.
Így például csak azok a környezetvédelmi szabályok számítanak az indikátorba, amelyek az összes vállalkozásra vonatkoznak. Hasonlóképpen nem kell számításba venni a villamos áram, víz, gáz, szemétszállítási szolgáltatások bevezetéséhez kapcsolódó folyamatokat, kivéve, ha ezeket külön szabályozás teszi kötelezôvé induló cégek esetében.

A fenti munkamódszert azután a fent felsorolt (a) - (j) üzleti folyamatok mindegyikére kidolgozzák, és az adatgyújtést - például 2006-ban - a kutatásban részt vevő 175 ország mindegyikében elvégzik.

\section{A ,Doing Business” kutatás általános eredményei}

A kutatás legalapvetốbb eredménye, hogy a szegény országok szabályozzák a leginkább erooforrás- és idôrabló módon vállalkozásaikat. A harmadik világ országaiban a gazdasági fejlődés lassúsága nem kis részben azzal magyarázható, hogy a vállalkozások szabályozási terhei nagyobbak, ami csökkenti a termelékenységet, növeli az informális gazdaság részarányát és a korrupciót.

A „Doing Business” kutatás indikátorai a másik végleten elhelyezkedő országokról is szólnak: eszerint a vállalkozások számára a legkedvezóbb szabályozást biztosító országokat nem a szabályozás hiánya jellemzi, hanem az, hogy a vállalkozásaik számára kevésbé költséges és terhes módon szabályoznak. Például Ausztráliában mindössze 2 eljárás szükséges egy vállalkozás elindításához, ugyanakkor Bolíviában 15, Csádban pedig 19. Az idő mértékegységeivel kifejezett indikátorok is erról tanúskodnak: míg a kanadai Torontóban 2 nap elég egy vállalkozás elindításához, addig Mozambik fóvárosában, Maputóban erre 153 nap szükséges.

Elméleti munkák sora igazolta, hogy a tulajdon védelmének intézményesítettsége, a hitelezốk védelme a gazdasági fejlődés igen fontos faktora. ${ }^{15}$ Esettanulmányok sokasága igazolta, hogy a fejlődô világban a kisemberek vagyona a tulajdonbiztonság gyengeségei miatt nem tud kisvállalkozásokban hasznosulni, így ez a körülmény önmagában is konzerválja a gazdasági elmaradottságot. ${ }^{16}$ A Világbank „Doing Business” felméréssorozatában erre a jelenségre vonatkoznak azok az indikátorok, amelyek az üzleti tranzakciós költségek mértékét, a tulajdonjog bejegyeztetésének gyorsaságát és olcsóságát, valamint a tartozások behajthatóságát mérik. Míg Helsinkiben 3 eljárás szükséges egy kereskedelmi ingatlan bejegyeztetéséhez, addig a nigériai Abujában ehhez 21 eljárás szükséges, és a bejegyeztetés költsége az ingatlan értékének 30\%-át is elérheti. Míg Tokióban az adós csődje esetén a hitelező több mint 90 centhez jut minden egyes neki járó dollár után, 
addig az indiai Mumbaiban (Bombay) hasonló helyzetben csak 13 centet kap vissza.

A szabályozási reformok esélye szempontjából optimizmusra ad okot, hogy azok a szabályozási megoldások, amelyek beváltak a fejlett országokban, sok esetben jól múködnek a fejlődő országokban is. Ez a jelenség rácáfol arra a gyakran hangoztatott elvre, hogy minden régiónak megvan a maga sajátos útja (,„One size doesn't fit all'). Például a vállalkozásindításhoz szükséges eljárások (statisztikai bejegyzés, adó- és társadalombiztosítási regisztráció stb.) számának a minimálisra való csökkentése és a regisztrációs folyamat elektronikussá alakítása kiváló eredményekhez vezetett Kanadában, Szingapúrban, Lettországban és Mexikóban, de Hondurasban, Vietnamban, Moldáviában és Pakisztánban is.

\section{A ,Doing Business” kutatás Magyarországra vonatkozó eredményei}

Magyarország tartósan rossz helyet foglal el azon a 2006-ban 175 országot bemutató listán, amelyet a gazdálkodási környezet vállalkozásbarátságossága alapján állítottak össze. ${ }^{17}$ Ebben az évben Magyarország a 66ik helyet foglalta el. Ez az eredmény sokkal rosszabb, mint a balti országoké, sốt elmarad Szlovákia, Románia, Csehország és Bulgária helyezése mögött is. A közép- és kelet-európai posztszocialista országok körében csak Lengyelország, Montenegró, Macedónia, Moldávia és Szerbia mutatott fel gyengébb teljesítményt, mint Magyarország.

Hasonlítsuk össze Magyarország szabályozási környezetét a vállalkozásbarátság jelzőszámai szerint a vele szomszédos két állammal, Romániával és Szlovákiával.

Gyengeségek. 2006-ban a magyar szabályozási környezet az üzleti folyamatok alábbi területein volt kevésbé vállalkozásbarát, mint a vele szomszédos két fenti ország:

- A vállalkozások indítása. Magyarországon 2003-ban nemzetközi összehasonlításban még meglehetősen költséges volt egy új vállalkozás elindítása. A következó két év alatt jelentős javulás állott be e területen, de nemcsak Magyarországon, hanem a tókevonzásban versenytársnak számító országokban is, így például Szlovákiában is.

- A szükséges hatósági és közüzemi engedélyek beszerzése.

- A tulajdon bejegyzése.
Közepes pozíció. Magyarország a két szomszédos országgal összevetve átlagos teljesítményt nyújtott az alábbi területeken, vagy nem volt lényeges különbség a teljesítményben:

- munkaadás mennyire vállalkozásbarát,

- hitelhez jutás,

- befektetővédelem,

- adózás,

- külkereskedelem,

- csődeljárás és végelszámolás.

Erốsség: A megvizsgált tíz üzleti folyamat közül 2006-ban a magyar szabályozási környezet csak egy üzleti folyamat esetében volt versenyképesebb a két szomszédos országhoz képest, és ez a szerződéses megállapodások kikényszerítésének területe volt.

A fenti besorolást józan fenntartással kell kezelni, mert nem minden szempontból felel meg a tapasztalatoknak. Az induló vállalkozások bejegyzésének adminisztratív terhe, az ezzel kapcsolatos munka idôtartama és a várakozási idő, valamint a vállalkozásindítással kapcsolatos költségek Magyarországon már 2006-ban is igen alacsonyak voltak. ${ }^{18}$ Magyarországon a kis- és közepes vállalkozások tớkéhez juttatásával, speciálisan azok hitelezésével kapcsolatos hazai intézkedések jelentôs eredményeket mutatnak fel, és bár a vállalkozásfejlesztési politika e részterülete folyamatos fejlesztést igényel, ennek fejlettsége nem marad el a szomszédos országokkal való összehasonlításban sem. ${ }^{19,20}$

\section{A szabályozási hatásvizsgálati projektek általános módszertani elemei}

A hatáselemzés célja a különféle társadalmi-politikai beavatkozások, intézkedések eredményességének megállapítása. Feladata, hogy tapasztalati tényeken alapuló kutatás során oksági kapcsolatok fennállását és azok erősségét állapítsa meg egyfelól a vizsgált intézkedések, másfelól az ezeket követô változások között.

Ok-okozati kapcsolatok igazolásának logikai kerete. A vizsgálatok során többnyire tisztázni kell, hogy mit tekintünk változásnak, és mihez viszonyítva értelmezzük azt:

- a beavatkozás által érintett csoport múltbeli teljesítményéhez, magatartásához képest,

- egy másik, a beavatkozás által nem érintett csoportban bekövetkezett változáshoz képest,

- egy feltételezett helyzethez képest, amiben a beavatkozás nem történt meg, de egyébként minden tekintetben azonos a vizsgálati helyzettel, vagy

- ezek egy kombinációjához képest? 
A hatások kimutatásához először is meg kell válaszolni azt a kérdést, hogy egyáltalán bekövetkezett-e a kívánt változás. Előfordulhat, hogy a valóságosan érvényesülő hatás nem látszik, mert egy ellentétes irányú hatásmechanizmus kioltja azt. Ezt a jelenséget nevezi a társadalomkutatási módszertan szakirodalma szuppresszor-hatásnak. Ha a hatás bekövetkezett, még akkor is nyitott kérdés, hogy valóban a beavatkozás hozta-e létre ezt a kedvezô változást, vagy valamilyen más hatásmechanizmus? Ilyen egyéb mechanizmus lehet (a) a véletlen, (b) hogy nem a vizsgált beavatkozás hozta létre a kedvezô változást, hanem az valójában egy másik, ugyanabban az irányban ható másik oksági tényezőnek köszönhető, vagy hogy (c) a beavatkozás által előidézett változást csak az érintettek olyan körében vizsgáljuk, amelyben a kedvező hatás érvényesülni tudott. Az utóbbi hibatípust szaknyelven függô változó szerinti szelekciónak hívják, angolul ,selection on the dependent variable".

A vizsgálat idózítése. A hatásvizsgálat alkalmazható expost és exante módon. Az expost mérés egy megvalósult szabályozás következményeit méri. Az exante mérés pedig egy (még) meg nem valósított szabályozás jövőbeni következményeit becsüli fel.

A vizsgálatok adatforrásai és az érintettekkel folytatott konzultációk. A szabályozási hatásvizsgálatok a gyakorlatban jogi, intézményi és gazdálkodási információkon alapulnak, amiket csak kedvezố esetben egészítenek ki statisztikai adatok. Mindehhez a kutatók államigazgatási és vállalati interjúk sorát valósítják meg. A kvalitatív módszerek alkalmasak arra, hogy a nehezen strukturálható problémák esetén feltárják a hatásmechanizmusokat és a vállalati és intézményi jellegú magatartásmintákat.

- A kormányzati interjúk célja, hogy az elôterjesztő, a szabályozásért felelős hatóság és a rokon jellegú érintett kormányszervek munkatársait, szakértőit megkérdezzék: mik a tervezett intézkedés bevezetésének és folyamatos implementációjának feltételei, következményei.

- A legtöbb hatásvizsgálati projektben megkérdezik a szabályozás által érintett vállalatok képviselőit is a várható hatásokról. A szabályozás célcsoportjával lehet direkt vagy indirekt módon kommunikálni. Az utóbbira példa a vállalkozói érdekcsoportok képviselőivel való érdekegyeztetés. Újabb konzultációs módszer az internet használatával történő kommunikáció. Vannak olyan országok, ahol vállalkozások ezreire kiterjedő felmérések keretében érdeklődnek az óket sújtó adminisztratív terhekrôl (pl. Belgium, Franciaország, Ausztrália). Kérdőíves vállalati felmérésre és az ezt követő regresszióelemzésre ritkán van lehetőség, ennek előnye, hogy a vállalkozások széles körét megszólaltatják, és szignifikáns eredményt adnak.

Alternatívák, forgatókönyvek. Egy szabályozási javaslat gazdasági hatásainak megállapítása általában a következô elemekból áll.

- Kiinduló forgatókönyv (baseline). Azt vizsgálja, hogy mi lenne a helyzet, ha a szabályozás nem kerülne végrehajtásra. Ez a ,business as usual” vagy ,doing nothing” nevú forgatókönyv.

- Feltételezett beavatkozások forgatókönyve. Azt a hipotetikus helyzetet írja le, hogy a szabályozást vagy annak egy alternatíváját bevezetik. Ha több alternatív bevezetési módot is meg kívánnak vizsgálni, akkor külön-külön mindegyik esetében a kiszámított hatásokat össze kell hasonlítani a kiinduló forgatókönyvben rögzített helyzettel.

Az érintett vállalkozások köre. Tisztázni kell a szabályozás által érintett vállalatcsoport körét és annak méretét (pl. az érintett vállalkozások számát). A jellegzetes jogszabályok esetében ez nem feltétlenül esik egybe olyan hagyományos statisztikai kategóriákkal, mint amilyen az ágazat- vagy a vállalatnagyság-kategória. (Például a jogszabály vonatkozhat olyan vállalkozásokra, amelyek családtagokat foglalkoztatnak, vagy például amelyek nyugdíjasokat foglalkoztatnak.) Ha van mód rá, akkor - kontrollcsoport jelleggel - érdemes a megfigyelést kiterjeszteni egy olyan vállalati körre is, amelynek összetétele a jogszabály által érintett körhöz hasonló, de valamilyen oknál fogva a jogszabály hatókörén kívül esik.

A szabályozás alá esó cégek reakciója (business response). Előre kell jelezni és - amennyiben lehetséges - számszerúsíteni kell, hogy az érintett vállalkozásoknak mennyit kell beruházniuk üzleti folyamataikba és a termékekbe abból a célból, hogy eleget tegyenek a szabályozás követelményeinek, valamint a szabályozás hogyan befolyásolja árbevételüket. Ezen belül szokás elkülöníteni az egyes hatástípusokat:

- Közvetlen vállalati hatások (direct impacts). Ezt általában a szabályozásnak való megfelelés érdekében a vállalkozásoknál felmerülő közvetlen költségek összességeként értelmezik. Ez a folyamatok és termékek változtatásának összes tókeés folyóköltségeit, valamint a szabályozásnak való megfelelés demonstrálásának költségeit foglalja magába.

- Közvetett vállalati hatások (indirect impacts). A hatásvizsgálat során figyelembe kell venni a szabályozás által a vállalkozásoknak okozott piaci térnyerést/térvesztést, kibocsátásuk növe- 
kedését/csökkenését, termelékenységük, versenyképességük változását. A szabálykövetési költségek ugyanis beépülnek az árakba, befolyásolják a szabályozás alá esô szektor kibocsátását és versenyképességét is. Közvetett hatásnak számítanak a vállalatokat érintó megoszlási hatások (distributional effects): az összességében leginkább költséghatékony szabályozás sem vonzó, ha bizonyos csoportokat vagy szektorokat rendkívül aránytalanul terhel.

A kormányzatot érintó implementációs költségek (government regulatory cost). A kormányzatnak a szabályozással kapcsolatos költsége az a költség, ami a kormányzatot terheli a szabályozás alkalmazása, ellenơrzése és betartatása és az ezzel kapcsolatos intézményfejlesztés kapcsán. Ebbe beletartoznak a betanítás, a pereskedés, valamint az engedélyek elóállításának és az ügyfelekhez való eljuttatásának költségei is.

Haszonnak, pozitív hatásnak tekintendő a szabályozni kívánt vállalati magatartás adott aspektusának javulása, így a környezetvédelemben, az élelmiszerbiztonságban vagy a közlekedésbiztonságban elért kedvezô változás. Közvetlen szabálykövetési haszonnak tekinthetô a fentebb említett költségek csökkenése. Így például, ha a szabályozás egy korábbi, kedvezőtlenebb szabályozást vált fel, akkor pozitív hatásként regisztrálható a szabálykövetési költségek csökkenése, a vállalatok beruházási és innovációs kedvének, valamint versenyképességüknek fokozódása. Míg a szabályozás költséghatásai szabványos vizsgálatokkal kiszámíthatók, addig a hasznok kvantifikálása az adott szabályozási területre (pl. a környezetvédelemre, az élelmiszerbiztonságra vagy a közlekedésbiztonságra) jellemzô szakmaspecifikus eljárások igénybevételét igényli, és gyakran nem is megvalósítható.

Elemzési lehetốségek. Az összegyưjtött adatok sok esetben módot adnak arra, hogy a kutatók segítségükkel bizonyos számításokat végezzenek. Ilyenek a költség-haszon elemzés, a költséghatékonyság-elemzés, a szabálykövetési költségek elemzése (compliance cost analysis), a kockázatelemzés, a különböző többkritériumos módszerek (multicriteria analysis), valamint az ágazati és makrogazdasági modellek.

\section{Európai javaslat a költséghatások szabványosítására: a Standard Cost Modell}

Az európai országok 2003 ôszén az adminisztratív terhek elemzésére és csökkentésére nemzetközi hatásvizsgálati hálózatot alapítottak. A hálózat tagjai egységes hatásvizsgálati módszertan, az úgynevezett Standard Cost Modell (SCM) mellett kötelezték el magukat.
A hálózatban az alábbi országok illetékes kormányhivatalai, illetve regionális hatóságai vesznek részt: Ausztria, Belgium, Cseh Köztársaság, Dánia, Egyesült Királyság, Észtország, Finnország, Franciaország, Írország, Lengyelország, Lettország, Luxemburg, Hollandia, Magyarország, Németország, Norvégia, Olaszország és Svédország. A szervezetbe az OECD is belépett, és már az ott elfogadott közös módszert használta, amikor egy széles körú felmérés ${ }^{21}$ során tagországait a vállalkozásokra, hivatalokra és állampolgárokra nehezedô adminisztratív terhek szempontjából jellemezte.

A Standard Cost Model-t (SCM) ${ }^{22}$ eredetileg Hollandiában fejlesztették ki, ma már számos országban (Dánia, Norvégia, Svédország, Egyesült Királyság) használatos. A különböző szintú szabályozások által a vállalkozásoknak okozott adminisztratív teher (administrative burden) számszerúsítésére szolgál. E módszerrel nemcsak egy bizonyos jogszabály hatása válik mérhetôvé, hanem ezek egyes aggregátumainak - a szabályozások valamely részterületének, sốt a vállalkozásokat érintő összes szabályozásnak - a hatása is. Alkalmas továbbá egy egyszerúsítő javaslat, vagy egy új törvény adminisztratív következményeinek a számszerúsítésére is.

A módszer egyértelmúen definiálja, hogy a vállalkozások mely költségeit kell a szabályozás okozta költségnek, az SCM szóhasználatában a szabályozás okozta adminisztratív tehernek tekinteni.

A Standard Cost Model kizárólag azt méri, hogy mekkora az a költség, amelyet a vállalkozás kizárólag azért szenved el, hogy megfeleljen a vizsgált szabályozás követelményeinek. Így például a vállalkozás vezetésével kapcsolatos adminisztratív feladatok költségei nem feltétlenül számítanak bele az SCM által számított, a szabályozás okozta adminisztratív terhekbe. A vállalkozások adminisztratív terhe általánosságban szélesebb fogalom, mint amit egy konkrét szabályozás kapcsán, annak következményeként azonosíthatunk, ez ugyanis azon adminisztratív tevékenységek költségét is magába foglalja, amelyeket a vállalkozás akkor is folytatna, ha a vizsgált szabályozást eltörölnék.

A módszer alkalmazása esetén minden adminisztratív tevékenységnek több költségparamétere (cost parameters) van, melyeket össze kell gyújiteni:

- egységár, mely a tarifából, azaz a vállalkozáson belül végzett adminisztratív tevékenység órabérköltségéból plusz a rezsiköltségból számítható ki, vagy pedig kihelyezett adminisztratív tevékenység óradíja; 
- idótartam, az adminisztratív tevékenységre fordítandó idô mennyisége;

- mennyiség, amely a szabályozás által érintett cégpopuláció, azaz a vállalkozások számának, és annak a szorzata, hogy hányszor kell egy évben elvégezni az adott adminisztratív tevékenységet, azaz annak mekkora a gyakorisága.

A fenti paraméterek és az SCM alapformula segítségével kiszámítható egy adott adminisztratív tevékenység költsége: A szabályozás következményeként a vállalatok összességének szintjén felmerülő adminisztratív költség $=$ Ár $\times$ Idô $\times$ Mennyiség $=$ Ár $\times$ Idő $\times$ populáció $\times$ gyakoriság.

Példa az SCM formula alkalmazására: egy adminisztratív tevékenység 3 munkaórát emészt fel (idő), az adminisztratív alkalmazottak órabére 10 euró (tarifa). A tevékenységre 100.000 vállalkozásban kerül sor (populáció), és évente kétszer hajtandó végre (gyakoriság). Az adminisztratív tevékenység teljes költsége így $10 \times 3 \times 100.000$ $\times 2=6.000 .000$ euró. Ehhez még hozzáadódhat a szabályozásnak való megfelelés miatt szükséges beszerzések éves átlagköltsége.

Az SCM alapkoncepciója és megfigyelési egysége az úgynevezett „,szokásosan hatékony vállalkozás” (normally efficient business). Ez azt a vállalkozást jelenti az adott célcsoporton belül, amelyik az adminisztratív tevékenységeit szokásosan, normálisan végzi, tehát se nem sokkal rosszabb, se nem sokkal jobb hatékonysággal, mint ami a célcsoportbeli vállalkozásokra jellemzố. A szokásosan hatékony vállalkozást a célcsoport tipikusnak tekinthetố vállalkozásai, illetve a vállalkozások kihelyezett feladataival foglalkozó külső partnerek, illetve egyéb szakértók körében végzett interjúkkal lehet megtalálni.

\section{Lábjegyzet}

${ }^{1}$ Értékes megjegyzéseiért köszönetet mondok dr. Szirmai Péter igazgató úrnak (Budapesti Corvinus Egyetem, Vállalkozásfejlesztési Intézet).

2 OECD (1997): Assessing the Impacts of Proposed Laws and Regulations, SIGMA PAPER, No. 13., OECD, Párizs, 92 oldal. Továbbá: OECD (2001): Improving Policy Instruments through Impact Assesment, SIGMA PAPER, No. 31., OECD, Párizs, 52 oldal.

${ }^{3}$ OECD Economic Outlook (1999): Cross-Country Patterns of Product Market Regulation, Párizs: OECD, p. 179-189.

${ }^{4}$ Például: OECD Guiding Principles for Regulatory Quality and Performance. Az OECD Tanácsának határozata, 2005 április.

5 Például Magyarországról: OECD Reviews of Regulatory Reform - Regulatory Reform in Hungary. OECD, 2000 július.
${ }^{6}$ OECD (2003): From Red Tape to Smart Tape. Administrative Simplification in OECD Countries. OECD Publishing. Párizs, 261 oldal.

7 OECD (2005): SME and Entrepreneurship Outlook. OECD, Párizs

${ }^{8}$ OECD (2003): From Red Tape to Smart Tape. Administrative Simplification in OECD Countries. OECD Publishing. Párizs, 261 oldal.

${ }^{9}$ Futó Péter - Tardos Ádám - Karajánnisz Manolisz - Homoki Máté (2005): Az elektronikus hálózati kommunikáció társadalmi, gazdasági és kormányzati hasznosítása Magyarországon. Kézirat, 106 oldal. Ariosz Kft., Budapest. A tanulmány 2007 januárjától letölthetô a Gazdasági és Közlekedési Minisztérium honlapjáról. Konkrétan a http://www.magyarorszag.hu/ weboldalról, ld.: A központi kormányzat szerveinek elektronikus kormányzati törekvései c. fejezetet.

${ }^{10}$ OECD Economic Outlook (1999): Cross-Country Patterns of Product Market Regulation, Párizs: OECD, p. 179-189.

${ }^{11}$ A kompozit indexekról bővebben ld.: Lengyel György (szerk.) (2002): Indikátorok és elemzések. Kézirat, 127 oldal, Budapesti Közgazdasági és Államigazgatási Egyetem, Budapest.

${ }^{12}$ Például: The Global Competitiveness Report 2006-2007. World Economic Forum. Palgrave Macmillan, ISBN: 1-4039-9636-9

${ }^{13}$ Kane, T. - Holmes, Kim R. - O'Grady, Mary Anastasia (2007): 2007 Index of Economic Freedom. The Link Between Economic Opportunity and Prosperity. The Heritage Foundation, Washington

${ }^{14}$ Doing Business in 2004 - Understanding Regulation, Doing Business in 2005 - Removing Obstacles to Growth, Doing Business in 2006 - Creating Jobs, Világbank.

15 North, Douglass. C. (1990): Institutions, Institutional Change and Economic Performance, Cambridge, Cambridge University Press.

16 de Soto, Hernando (2000): The Mystery of Capital. Why Capitalism Triumphs in the West and Fails Everywhere Else. New York, Random House.

${ }_{17}$ Az országsorrend és valamennyi mutató 2007 januárjában excel táblázat formájában letölthető az alábbi weboldalról: www. doingbusiness.org/documents/Ease_of_DB_2007.xls

${ }^{18}$ Dr. Szirmai Péter igazgató úr szíves szóbeli közlése alapján, mely a Budapesti Corvinus Egyetemen, a vezetése alatt álló Vállalkozásfejlesztési Intézet Kisvállalkozás-fejlesztési Központjában folyó vállalkozóképzés gyakorlati tapasztalatain alapul.

${ }^{19}$ Futo, P. - Bateman, M. - Fiti, T. - Usenik, H. (2002): The local financial system and sustainable SME development in SouthEast Europe. Lessons from Hungary, Macedonia and Slovenia. Appeared as Chapter 4 (pages 83-125) of the following book: Small Enterprise Development in South-East Europe. Policies for Sustainable Growth. Editors: W. Bartlett, M. Bateman, M. Vehovec. Book published by Kluwer Academic Publishers, Boston-Dordrecht-London.

${ }^{20}$ Futo, P. (1997): The role of credit guarantees in financing Hungarian small businesses. Small Enterprise Development, June 1997. p. 34-40.

${ }^{21}$ OECD (2003): From Red Tape to Smart Tape. Administrative Simplification in OECD Countries. OECD Publishing. Párizs, 261 oldal.

${ }^{22}$ International Standard Cost Model Manual - Measuring and reducing administrative burdens for businesses. Kiadta az International SCM Network titkársága. 2005 október, 63 oldal, földrajzi megjelölés nélkül. Letölthetô a http://www. administrative-burdens.com/ weboldalról és az OECD internetes portáljáról. 
Az üzleti környezet indikátorai négy kiválasztott európai ország esetében, 2005-2006

\begin{tabular}{|c|c|c|c|c|c|c|}
\hline $\begin{array}{c}\text { Származtatott } \\
\text { index neve }\end{array}$ & Primér index neve & Mértékegység & $\begin{array}{l}\text { Egyesült } \\
\text { Királyság } \\
\end{array}$ & $\begin{array}{c}\text { Magyar- } \\
\text { ország }\end{array}$ & $\begin{array}{l}\text { Szlová- } \\
\text { kia }\end{array}$ & $\begin{array}{c}\text { Romá- } \\
\text { nia }\end{array}$ \\
\hline \multicolumn{2}{|c|}{$\begin{array}{l}\text { Mennyire vállalkozásbarát az ország? } \\
\text { (Ease of doing business) }\end{array}$} & Pozíció az országrangsorban & 6 & 66 & 36 & 49 \\
\hline & Bruttó nemzeti jövedelem / fő & USD / fő / év & 37600 & 10030 & 7950 & 3830 \\
\hline & Lakosság & Millió fó & 60,2 & 10,1 & 5,4 & 21,6 \\
\hline \multicolumn{2}{|c|}{ Vállalkozás indítása } & Pozíció az országrangsorban & 9 & 87 & 63 & 7 \\
\hline & $\begin{array}{l}\text { Kötelezô adminisztratív eljárások } \\
\text { száma kormányszervekkel, } \\
\text { ügyvédekkel, könyvelókkel }\end{array}$ & Darabszám & 6 & 6 & 9 & 5 \\
\hline & Időigény & Nap & 18 & 38 & 25 & 11 \\
\hline & Költség & Egy före jutó éves GDP \%-a & 0,7 & 20,9 & 4,8 & 4,4 \\
\hline & Minimális indulótóke & $\begin{array}{l}\text { Az egy före jutó éves nemzeti } \\
\text { jövedelem } \% \text {-a }\end{array}$ & 0 & 74,2 & 39,1 & 0 \\
\hline \multicolumn{2}{|c|}{$\begin{array}{l}\text { Engedélyezések (hivatalok, közmúvek, } \\
\text { földhivatal stb.). }\end{array}$} & Pozíció az országrangsorban & 46 & 143 & 47 & 116 \\
\hline & Eljárások száma & Darabszám & 19 & 25 & 13 & 17 \\
\hline & Idôigény & Nap & 115 & 212 & 272 & 242 \\
\hline & Költség & Egy före jutó éves GDP \%-a & 68,9 & 260 & 17,1 & 332,6 \\
\hline \multicolumn{2}{|c|}{ Munkaadás mennyire könnyú } & Pozíció az országrangsorban & 17 & 90 & 72 & 101 \\
\hline & $\begin{array}{l}\text { Alkalmazott felvételének } \\
\text { nehézsége }\end{array}$ & Index (1-100), 0 = könnyú & 11 & 11 & 17 & 33 \\
\hline & $\begin{array}{l}\text { Munkaidővel kapcsolatos } \\
\text { előírások szigora (0-100) } 20\end{array}$ & $\begin{array}{l}\text { Index }(1-100), 0=\text { engedé- } \\
\text { keny }\end{array}$ & 20 & 80 & 60 & 80 \\
\hline & $\begin{array}{l}\text { Alkalmazott elbocsátásának } \\
\text { nehézsége }\end{array}$ & Index (1-100), 0 = könnyú & 10 & 10 & 40 & 40 \\
\hline & A fenti három index átlaga & Index $(1-100)$ & 14 & 34 & 39 & 51 \\
\hline & Munkaadói költség & Fizetés \%-a & 11 & 35 & 35 & 33 \\
\hline & Elbocsátás költsége & Hány heti fizetés & 22 & 35 & 13 & 3 \\
\hline \multicolumn{2}{|c|}{ Tulajdon bejegyzése } & Pozíció az országrangsorban & 19 & 103 & 5 & 114 \\
\hline & $\begin{array}{l}\text { Eljárások száma (hatóságokkal, } \\
\text { jegyzókkel, ügyvédekkel) }\end{array}$ & Darabszám & 2 & 4 & 3 & 8 \\
\hline & Időigény & Nap & 21 & 78 & 17 & 150 \\
\hline & Költség & A vagyontárgy \%-a & 4,1 & 11 & 0,1 & 1,9 \\
\hline \multicolumn{2}{|c|}{ Hitelhez jutás } & Pozíció az országrangsorban & 1 & 21 & 13 & 48 \\
\hline & $\begin{array}{l}\text { Hitelbiztosítékra és csődeljárásra } \\
\text { vonatkozó törvények ereje }\end{array}$ & Index $(1-100)$ & 10 & 6 & 9 & 4 \\
\hline & $\begin{array}{l}\text { Hitelinformáció terjedelme, } \\
\text { minősége, hozzáférhetősége }\end{array}$ & Index $(0-6)$ & 6 & 5 & 3 & 5 \\
\hline & $\begin{array}{l}\text { Közület által nyilvántartott hitel- } \\
\text { képességi információk terjedelme }\end{array}$ & A felnőtt lakosság \%-a & 0 & 0 & 1 & 2,6 \\
\hline & $\begin{array}{l}\text { Magáncégek által nyilvántartott } \\
\text { hitelképességi információk terj. }\end{array}$ & A felnőtt lakosság \%-a & 86,1 & 5,9 & 45,3 & 5,5 \\
\hline
\end{tabular}




\begin{tabular}{|c|c|c|c|c|c|c|}
\hline $\begin{array}{l}\text { Származtatott } \\
\text { index neve }\end{array}$ & Primér index neve & Mértékegység & \begin{tabular}{|l|} 
Egyesült \\
Királyság
\end{tabular} & $\begin{array}{l}\text { Magyar- } \\
\text { ország }\end{array}$ & $\begin{array}{l}\text { Szlová- } \\
\text { kia }\end{array}$ & $\begin{array}{c}\text { Romá- } \\
\text { nia }\end{array}$ \\
\hline \multicolumn{2}{|c|}{ Befektetôvédelem } & Pozíció az országrangsorban & 9 & 118 & 118 & 33 \\
\hline & $\begin{array}{l}\text { Vitás ügyekben a kisebbségi } \\
\text { részvényes, kisrészvényes } \\
\text { információhoz való jogainak ereje }\end{array}$ & Index $(0-10), 0=$ gyenge & 10 & 2 & 2 & 9 \\
\hline & $\begin{array}{l}\text { Menedzser-igazgató felelósségre } \\
\text { vonhatósága }\end{array}$ & Index $(0-10), 0=$ gyenge & 7 & 4 & 4 & 5 \\
\hline & $\begin{array}{l}\text { Befektetô eljárásjogi helyzete } \\
\text { egy esetleges perben }\end{array}$ & Index $(0-10), 0=$ gyenge & 7 & 7 & 7 & 4 \\
\hline & A fenti három index átlaga & Index $(0-10)$ & 8 & 4,3 & 4,3 & 6 \\
\hline \multicolumn{2}{|l|}{ Adózás } & Pozíció az országrangsorban & 12 & 118 & 114 & 131 \\
\hline & Adófizetés gyakorisága & Darabszám per év & 7 & 24 & 30 & 89 \\
\hline & $\begin{array}{l}\text { Adóbevallások elkészítésének } \\
\text { időigénye }\end{array}$ & Óra per év & 105 & 304 & 344 & 198 \\
\hline & Összes fizetendő adó aránya & Profit $\%$-a & 35,4 & 59,3 & 48,9 & 48,9 \\
\hline \multicolumn{2}{|c|}{ Külkereskedelem } & Pozíció az országrangsorban & 14 & 76 & 88 & 35 \\
\hline & $\begin{array}{l}\text { Exportáláshoz szükséges } \\
\text { dokumentumok száma }\end{array}$ & Darabszám & 5 & 6 & 9 & 4 \\
\hline & Export időigénye & Nap & 12 & 23 & 20 & 14 \\
\hline & Export költsége & USD / konténer & 676 & 922 & 1015 & 1300 \\
\hline & $\begin{array}{l}\text { Importáláshoz szükséges } \\
\text { dokumentumok száma }\end{array}$ & Darabszám & 4 & 10 & 8 & 4 \\
\hline & Import időigénye & Nap & 12 & 24 & 21 & 14 \\
\hline & Import költsége & USD / konténer & 756 & 1137 & 1050 & 1200 \\
\hline \multicolumn{2}{|c|}{ Szerződéses megállapodások kikényszerítése } & Pozíció az országrangsorban & 22 & 12 & 59 & 45 \\
\hline & $\begin{array}{l}\text { Eljárások száma (hatóságokkal, } \\
\text { jegyzókkel, ügyvédekkel) }\end{array}$ & Darabszám & 19 & 21 & 27 & 43 \\
\hline & Idôigény & Nap & 229 & 335 & 565 & 335 \\
\hline & Költség & Követelés \%-a & 16,8 & 9,6 & 15,7 & 10,7 \\
\hline \multicolumn{2}{|c|}{ Csődeljárás és végelszámolás } & Pozíció az országrangsorban & 10 & 48 & 31 & 108 \\
\hline & Időigény & Év & 1 & 2 & 4 & 4,6 \\
\hline & Csődeljárás költsége & Vagyontárgy \%-a & 6 & 15 & 18 & 9 \\
\hline & Követelésbehajtás sikeressége & Követelés \%-a & 85,2 & 39,7 & 48,1 & 19,9 \\
\hline
\end{tabular}

* A jelzôszámok egységesen megválasztott, egyeztetett konkrét vállalkozástípusra és üzleti szituációra vonatkoznak. Forrás: Világbank, Doing Business in 2007. Filenév: Doing_Business_2007_Country_pages.pdf . Weboldal: http://www.doingbusiness. org/main/country-data-summaries.a

\section{Felhasznált irodalom}

OECD (1997): Assessing the Impacts of Proposed Laws and Regulations. SIGMA PAPER, No. 13., OECD, Paris, 92 o. OECD (2003): From Red Tape to Smart Tape. Administrative Simplification in OECD Countries. OECD Publishing. Paris, 261 o. OECD (2001): Improving Policy Instruments through Impact Assesment. SIGMA PAPER, No. 31., OECD, Paris, 2001., 52 o. SCM Network Secretariat: International Standard Cost Model Manual-Measuring and reducing administrative burdens for businesses. Kiadta az International SCM Network titkársága. 2005 október, 63 oldal, földrajzi megjelölés nélkül. Letölthetô a http://www.administrative-burdens. com/ weboldalról és az OECD internetes portáljáról

World Bank: ,Doing Business in 2004 - Understanding Regulation” ; „Doing Business in 2005 - Removing Obstacles to Growth” ; „Doing Business in 2006 - Creating Jobs”.

Cikk beérkezett: 2007. 6. hó

Lektori vélemény alapján átdolgozva: 2008. 1. hó 